\title{
Analysis of Anthropometric and Biomotor Components on the Performance of FIK UNP Basketball Athletes
}

\author{
Nugroho Susanto ${ }^{1 *}$, Windo Wiriadinata ${ }^{2}$, and Muhammad Sazeli Rifki ${ }^{3}$ \\ ${ }^{123}$ Faculty of Sport Science, Majoring in health and recreation, Universitas Negeri Padang \\ *Corresponding author. Email: nugrohosusanto@fik.unp.ac.id
}

\begin{abstract}
This study aims to determine the development of anthropometric and biomotor components of male basketball athletes of FIK UNP in 2020. This research is an ex post facto research. The data collection technique used was the measurement test. The research subjects of all male basketball athletes of FIK UNP were 15 athletes. There are two research instruments, namely anthropometric measurements and biomotor measurements. Anthropometric measurements using body weight and scales. Biomotor measurements used are sprint, sit and reach, handgrip, push up, sit up, back up, run test, wall pass, Multistage Fitness Test and vertical jump. The analysis technique used descriptive statistics with frequency in percentage form. The results showed that the body mass index was 22.3 in the normal category, the rate of velocity increased by 0.15 seconds, the level of flexibility increased by $1.00 \mathrm{~cm}$, the strength level in the right finger muscle increased in strength in the right finger muscle by $0.85 \mathrm{~kg}$, the strength level in the left finger muscles increased by $1.50 \mathrm{~kg}$, the strength level in the arm muscles increased by 11.55 , the strength level in the abdominal muscles increased by 5.15 , the strength level in the back muscles increased by 7,85 , at the agility level there was an increase of 0.20 seconds, at the coordination level there was an increase of 13.70, at the endurance level there was an increase of 1.25 and at the power level there was a decrease of $1.15 \mathrm{~cm}$.
\end{abstract}

Keywords: anthropometry, biomotor, basketball

\section{INTRODUCTION}

Basketball is a game that is popular throughout the world. Basketball game is a game played by 2 teams, each consisting of 5 players [1]. In basketball, an athlete is required to be able to master basic techniques, understand tactics, physical skills and maturity in playing.

In basketball, there are anthopometric and biomotor components. The anthropometric component is the science of measuring the composition of the human body which describes the dimensions of the body. Examples included in the anthropometric component of basketball are body weight, height and fat thickness. The biomotor component is the ability of human movement which is influenced by the condition of the organ systems in the body. Examples of biomotor components in basketball include speed, agility, strength, coordination and endurance. According to Sukadiyanto, biomotor is the ability of human movement which is influenced by the condition of the organ systems in the body. [2]. Assessment of the biomotor component and anthropometry of athletes is one of the most important problems in modern sports in Indonesia, many tests are used for selection procedures, for players candidates 
when screening, or to monitor training progress.

National Student Sports Week / Pekan Olahraga Mahasiswa Nasional is a national level sports event which is held every 2 (two) years, as a sporting event that is part of the history and involvement of the nation's children in building the world of sports in the country. POMNAS has a role in fostering and searching for superior seeds, especially for students who come from universities throughout Indonesia. Based on the results of the analysis and research data from the POMNAS results in 2017 and 2019, the FIK UNP basketball team has not been able to show results to be proud of in achieving achievements even though the various efforts made in preparing athletes and basketball teams sent to POMNAS have been maximized.

There are several processes that must be carried out by male basketball athletes of FIK UNP team to be better prepared to face matches at official events. This preparation includes, increasing physical, technical, tactical, and mental training. Physical exercise is a biomotor component that must be improved in order to achieve maximum results. According to Pomohaci. M, \& Sopa. S. I. This study shows that physical activity can affect children's development both in biomotor and anthropometric components as well as related to health functions in the body [3].

Based on the existing facts, good anthropometric and biomotor components are needed for an athlete to achieve the highest achievement, thus the facts above are a good basis for athletes to improve exercise. In addition, it is important for a trainer to know the biomotor of each trainee as data and consideration for the next event. According to Oloo. O. M., Wakesa. J., Sabiri. E., Kweyu. I., the results of this study present that the models that can be used to predict an athlete's sport are anthropometric and biomotor variables [4]. These two components can be used to orient athlete's training towards a particular sport. The benefits of these two components can be useful in improving athlete's performance. The conclusion is that anthropometric and bimoor characteristics are the most influential factors in determining a good athlete's performance in sports. On this basis, the researcher wants to analyze the anthropometric and biomotor components of basketball athletes at FIK UNP, namely by looking at the development of the physical conditions possessed by each of male basketball athletes of FIK UNP.

\section{METHOD}

This type of research is research that uses ex post facto research. Data collection techniques using tests and measurements. Suharsimi Arikunto (2010: 3) states that descriptive research is research that does not intend to test hypotheses, but only describes what it is about a variable, symptom or situation. The purpose of this study was to analyze the anthropometric and biomotor components of male basketball athletes of FIK UNP.

Population is a generalization area consisting of objects or subjects that have certain qualities and characteristics that are determined by the researcher for study, and then draw conclusions. The population is the entire research subject. The population in this study were all basketball athletes of FIK UNP, totaling 15 male athletes.

The instruments in this study used standardized tools and their validity and reliability had been tested The instruments in this study were as follows: For the anthropometric component, namely tests of height and weight and fat thickness. For the Biomotor components are speed tests, flexibility tests, strength tests, agility tests, coordination tests and endurance tests.

Data analysis in this study was carried out by calculating the data and looking for the magnitude of the percentage relative frequency with the following formula $[5] .:$

\section{$P=F / N X 100 \%$}

Description:

$\mathrm{P}=$ Percentage

$\mathrm{F}=$ Frequency

$\mathrm{N}=$ Number of respondents 
Furthermore, the research data were analyzed, and then presented in five categories, namely: excellent, good, moderate, poor, and very poor.

\section{RESEARCH RESULTS}

Anthropometric Measurement Results

Anthropometry is a measurement of human body dimensions such as length, width, circumference, and skinfold, using surface landmarks for reference. For anthrometric measurements, in this case the researcher only focuses on the athlete's height and weight. From the results of the athlete's anthropometric measurement test, the following results were obtained:

Table 1.Anthropometric measurement test for basketball athletes of FIK UNP

\begin{tabular}{|c|c|c|c|c|}
\hline No & Name & $\begin{array}{c}\text { Weight } \\
(\mathbf{k g})\end{array}$ & $\begin{array}{c}\text { Height } \\
(\mathbf{c m})\end{array}$ & BMI \\
\hline 1 & Aldi R & 65 & 170 & 22.5 \\
\hline 2 & Rahman Juni A & 65 & 175 & 21.2 \\
\hline 3 & Mulya A P & 60 & 168 & 21.3 \\
\hline 4 & Agung Wibawa & 55 & 165 & 20.2 \\
\hline 5 & Vandri G & 60 & 177 & 19.2 \\
\hline 6 & Yuna F & 59 & 164 & 21.9 \\
\hline 7 & Dodi Irpan & 68 & 178 & 21.5 \\
\hline 8 & Farel R & 70 & 165 & 25.7 \\
\hline 9 & Daffa Erbaik & 75 & 179 & 23.7 \\
\hline 10 & M. Syafril & 60 & 172 & 20,3 \\
\hline 11 & Gali Rahman & 58 & 174 & 19.2 \\
\hline 12 & Andra Priadi & 70 & 165 & 25.7 \\
\hline 13 & Rudinal R & 55 & 165 & 20.2 \\
\hline 14 & Edo Ilham & 70 & 165 & 25.7 \\
\hline 15 & Zikri P & 68 & 180 & 21.0 \\
\hline & & & & \\
\hline
\end{tabular}

Speed Test Measurement Results

Table 2. Speed Test Results

\begin{tabular}{|c|c|c|c|c|c|}
\hline \multirow{2}{*}{ No } & \multirow{2}{*}{ Criteria } & \multicolumn{2}{|c|}{ Start } & \multicolumn{2}{c|}{ End } \\
\cline { 3 - 6 } & & $\mathrm{F}$ & $\%$ & $\mathrm{~F}$ & $\%$ \\
\hline 1 & Excellent & 0 & 0 & 1 & 6.67 \\
\hline 2 & Good & 10 & 66.67 & 8 & 53.3 \\
\hline 3 & Moderate & 2 & 13.3 & 2 & 13.3 \\
\hline 4 & Poor & 2 & 13.3 & 3 & 20.01 \\
\hline 5 & Very Poor & 1 & 6.67 & 1 & 6.67 \\
\hline \multicolumn{2}{|c|}{ Totals } & 15 & 100 & 15 & 100 \\
\hline
\end{tabular}

Description : F= Frequency, \%=Percentage

From the table above, it can be seen that the speed level of male basketball athletes of FIK UNP at the beginning was good, with the most frequent consideration being in good criteria, with 10 people or $66.67 \%$. In the end, the speed level of male basketball athletes of FIK UNP was good, considering the highest frequency was in good criteria, with 8 people or $53.3 \%$. whereas based on the average speed level, there was an increase in speed of 0.9 so that it can be said that there has been a development in the speed level of the male basketball athletes of FIK UNP.

Flexibility Measurement Test Results

Table 3. Flexibility Test

\begin{tabular}{|c|c|c|c|c|c|}
\hline \multirow{2}{*}{ No } & \multirow{2}{*}{ Criteria } & \multicolumn{2}{|c|}{ Start } & \multicolumn{2}{c|}{ End } \\
\cline { 3 - 6 } & & $\mathrm{F}$ & $\%$ & $\mathrm{~F}$ & $\%$ \\
\hline 1 & Excellent & 1 & 6.67 & 2 & 13.3 \\
\hline 2 & Good & 7 & 46.69 & 5 & 33.35 \\
\hline 3 & Moderate & 3 & 20.01 & 5 & 33.35 \\
\hline 4 & Poor & 3 & 20.01 & 3 & 20.01 \\
\hline 5 & Very Poor & 1 & 6.67 & 1 & 6.67 \\
\hline \multicolumn{2}{r|}{ Totals } & 15 & 100 & 15 & 100 \\
\hline
\end{tabular}

Description: F=Frequency, \%=Percentaqe

From the table above, it can be seen that the level of flexibility of male basketball athletes of FIK UNP is good, with the consideration that the highest frequency is 
in good criteria, with 7 people or $46.69 \%$. At the end, the level of flexibility of male basketball athletes of FIK UNP was moderate, considering that the highest frequency was in the moderate criteria, with 5 people or $33.35 \%$. whereas based on the average level of flexibility there was an increase of 1.3 , so that it can be said that there has been a development in the level of flexibility of male basketball athletes of FIK UNP.

\section{Finger Muscle Strength Test Results}

In this case there are two results of the finger muscle strength test, namely the right and the left.

Table 4. Right Finger Muscle Strength Test

\begin{tabular}{|c|c|c|c|c|c|}
\hline \multirow{2}{*}{ No } & \multirow{2}{*}{ Criteria } & \multicolumn{2}{|c|}{ Start } & \multicolumn{2}{c|}{ End } \\
\cline { 3 - 6 } & & $\mathrm{F}$ & $\%$ & $\mathrm{~F}$ & $\%$ \\
\hline 1 & Excellent & 1 & 6.67 & 2 & 13.3 \\
\hline 2 & Good & 5 & 33.35 & 5 & 33.35 \\
\hline 3 & Moderate & 5 & 33.35 & 7 & 46.69 \\
\hline 4 & Poor & 3 & 20.01 & 1 & 6.67 \\
\hline 5 & Very Poor & 1 & 6.67 & 1 & 6.67 \\
\hline \multicolumn{2}{|c|}{ Totals } & 15 & 100 & 15 & 100 \\
\hline
\end{tabular}

Description: $\mathrm{F}=$ Frequency, \%=Percentage

From the table above, it can be seen that the level of muscle strength in the right finger of male basketball athletes of FIK UNP, at the beginning was moderate, considering that the highest frequency was moderate, with 5 people or $33.35 \%$. The level of muscle strength of the right finger of male basketball athletes of FIK UNP, at the end was moderate considering that the highest frequency was in the poor criteria, with 7 people or $46.69 \%$. Meanwhile, based on the average muscle strength level of the right finger there was an increase in the muscle strength of the right finger by 0.84 , so it can be said that there has been a development in the strength level of the right finger of male basketball athletes of FIK UNP.

From the test results, the level of muscle strength of the left finger of male basketball athletes of FIK UNP can be categorized. The calculations are presented in the table as follows:

Table 5. Left Finger Muscle Strength Test

\begin{tabular}{|c|c|c|c|c|c|}
\hline \multirow{2}{*}{ No } & \multirow{2}{*}{ Criteria } & \multicolumn{2}{|c|}{ Start } & \multicolumn{2}{c|}{ End } \\
\cline { 3 - 6 } & & $\mathrm{F}$ & $\%$ & $\mathrm{~F}$ & $\%$ \\
\hline 1 & Excellent & 1 & 6.67 & 1 & 6.67 \\
\hline 2 & Good & 2 & 13.3 & 3 & 20.1 \\
\hline 3 & Moderate & 7 & 46.69 & 7 & 46.69 \\
\hline 4 & Poor & 3 & 20.01 & 2 & 13.3 \\
\hline 5 & Very Poor & 2 & 13.3 & 2 & 13.3 \\
\hline \multicolumn{2}{|c|}{ Totals } & 15 & 100 & 15 & 100 \\
\hline
\end{tabular}

Description: $\mathrm{F}=$ Frequency, $\%=$ Percentage

From the table above, it can be seen that the level of muscle strength of the left finger of male basketball athletes of FIK UNP, at the beginning was moderate, considering that the highest frequency was moderate, with 7 people or 46.69. At the end, the level of muscle strength of the left finger of male basketball athletes of FIK UNP was moderate, with the consideration that the highest frequency was in poor criteria, with 7 people or $46.69 \%$. Meanwhile, based on the average level of left finger muscle strength, there was an increase of 0.75 , so it can be said that there has been a development in the level of muscle strength of the left finger of male basketball athletes of FIK UNP.

\section{Arm Muscle Strength Test}

From the test results, the level of arm muscle strength of male basketball athletes of FIK UNP, can be categorized. These calculations are presented in the Table as following:

Table 6. Arm Muscle Strength Test

\begin{tabular}{|c|c|c|c|c|c|}
\hline \multirow{2}{*}{ No } & \multirow{2}{*}{ Criteria } & \multicolumn{2}{|c|}{ Start } & \multicolumn{2}{c|}{ End } \\
\cline { 3 - 6 } & & $\mathrm{F}$ & $\%$ & $\mathrm{~F}$ & $\%$ \\
\hline 1 & Excellent & 1 & 6.67 & 1 & 6.67 \\
\hline 2 & Good & 2 & 13.3 & 3 & 20.1 \\
\hline 3 & Moderate & 5 & 33.35 & 5 & 33.35 \\
\hline 4 & Poor & 5 & 33.35 & 3 & 20.1 \\
\hline 5 & Very Poor & 2 & 26.68 & 3 & 20.01 \\
\hline \multicolumn{2}{r|}{ Totals } & 15 & 100 & 15 & 100 \\
\hline
\end{tabular}


From the table above, it can be seen that the level of arm muscle strength of male basketball athletes of FIK UNP, at the beginning was poor, with highest frequency was in poor criteria, with 5 people or $33.35 \%$. The level of arm muscle strength of male basketball athletes at FIK UNP is moderate, with the consideration that the most frequency is in poor criteria, with 5 people or $33.35 \%$. Meanwhile, based on the mean level of arm muscle strength, there was an increase of 12.50 , so it can be said that there has been a development in the level of arm muscle strength of male basketball athletes of FIK UNP.

\section{Abdominal Muscle Strength Test}

From the test results, the level of abdominal muscle strength of the male basketball athletes of FIK UNP can be categorized. The calculations are presented in the table as follows:

Table 7. Arm Muscle Strength Test

\begin{tabular}{|c|c|c|c|c|c|}
\hline \multirow[t]{2}{*}{ No } & \multirow[t]{2}{*}{ Criteria } & \multicolumn{2}{|c|}{ Start } & \multicolumn{2}{|c|}{ End } \\
\hline & & $\mathrm{F}$ & $\%$ & $\mathrm{~F}$ & $\%$ \\
\hline 1 & Excellent & 1 & 6.67 & 0 & 0 \\
\hline 2 & Good & 2 & 13.3 & 2 & 13.3 \\
\hline 3 & Moderate & 7 & 46.69 & 8 & 53.36 \\
\hline 4 & Poor & 3 & 20.01 & 4 & 26.68 \\
\hline 5 & Very Poor & 2 & 13.3 & 1 & 6.67 \\
\hline & Totals & 15 & 100 & 15 & 100 \\
\hline
\end{tabular}

Description F=Frequency, \%=Percentage

From the table above, it can be seen that the level of abdominal muscle strength of male basketball athletes of FIK UNP at the beginning was moderate, with the most frequent consideration being in moderate criteria, with 7 people or $46.69 \%$. The level of abdominal muscle strength for male basketball athletes of FIK UNP, was moderate, considering that the highest frequency was in moderate, with 8 people or $53.36 \%$. Meanwhile, based on the average level of abdominal muscle strength, there was an increase of 3.15 , so it can be said that there has been a development in the level of abdominal muscle strength of male basketball athletes of FIK UNP.

\section{Back Muscle Strength Test}

From the test results, the level of back muscle strength of male basketball athletes of FIK UNP can be categorized. The calculations are presented in the table as follows:

Table 8. Back Muscle Strength Tests

\begin{tabular}{|c|c|c|c|c|c|}
\hline \multirow{2}{*}{ No } & \multirow{2}{*}{ Criteria } & \multicolumn{2}{|c|}{ Start } & \multicolumn{2}{c|}{ End } \\
\cline { 3 - 6 } & & $\mathrm{F}$ & $\%$ & $\mathrm{~F}$ & $\%$ \\
\hline 1 & Excellent & 0 & 0 & 1 & 6.67 \\
\hline 2 & Good & 4 & 26.68 & 5 & 33.35 \\
\hline 3 & Moderate & 5 & 33.35 & 5 & 33.35 \\
\hline 4 & Poor & 5 & 33.35 & 3 & 20.01 \\
\hline 5 & Very Poor & 0 & 0 & 1 & 6.67 \\
\hline \multicolumn{2}{|c|}{ Totals } & 15 & 100 & 15 & 100 \\
\hline
\end{tabular}

Description: $F=$ Frequency, $\%=$ Percentage

From the table above, it can be seen that the level of back muscle strength of male basketball athletes of FIK UNP 2015 was poor, considering the highest frequency was in poor criteria, with 5 people or $33.35 \%$. At the end, the level of back muscle strength of male basketball athletes of FIK UNP was poor, with the most frequent consideration being in moderate criteria, with 5 people or $33.35 \%$. Meanwhile, based on the average level of back muscle strength there was an increase of 5.32 so it can be said that there has been a development in the level of back muscle strength of male basketball athletes of FIK UNP.

\section{Agility Test}

From the test results, the level of agility of male basketball athletes of FIK UNP can be categorized. The calculations are presented in the table as follows: 
Table 9. Agility Tests

\begin{tabular}{|c|c|c|c|c|c|}
\hline \multirow{2}{*}{ No } & \multirow{2}{*}{ Criteria } & \multicolumn{2}{|c|}{ Start } & \multicolumn{2}{c|}{ End } \\
\cline { 3 - 6 } & & $\mathrm{F}$ & $\%$ & $\mathrm{~F}$ & $\%$ \\
\hline 1 & Excellent & 1 & 6.67 & 1 & 6.67 \\
\hline 2 & Good & 4 & 26.68 & 4 & 26.68 \\
\hline 3 & Moderate & 5 & 33.35 & 4 & 26.68 \\
\hline 4 & Poor & 5 & 33.35 & 4 & 26.68 \\
\hline 5 & Very Poor & 0 & 0 & 2 & 13.3 \\
\hline \multicolumn{2}{|c|}{ Totals } & 15 & 100 & 15 & 100 \\
\hline
\end{tabular}

Description: $F=$ Frequency, $\%=$ Percentage

From the table above, it can be seen that the level of agility of male basketball athletes of FIK UNP at the beginning was moderate, considering that the highest frequency was in the sufficient criteria, with 5 people or $33.35 \%$. The level of agility of male basketball athletes of FIK UNP was moderate, considering that the highest frequency was in moderate criteria, with 4 people or $26.68 \%$. Meanwhile, based on the average level of agility, there was an increase of 0.20 , so it can be said that there has been a development in the level of agility of male basketball athletes of FIK UNP.

\section{Coordination Test}

From the test results, the level of coordination of male basketball athletes of FIK UNP can be categorized. The calculations are presented in the table as follows:

Table 10. Coordination Tests

\begin{tabular}{|c|c|c|c|c|c|}
\hline \multirow{2}{*}{ No } & \multirow{2}{*}{ Criteria } & \multicolumn{2}{|c|}{ Start } & \multicolumn{2}{c|}{ End } \\
\cline { 3 - 6 } & & $\mathrm{F}$ & $\%$ & $\mathrm{~F}$ & $\%$ \\
\hline 1 & Excellent & 1 & 6.67 & 2 & 13.3 \\
\hline 2 & Good & 5 & 33.35 & 5 & 33.35 \\
\hline 3 & Moderate & 5 & 33.35 & 6 & 40.02 \\
\hline 4 & Poor & 3 & 33.35 & 2 & 26.68 \\
\hline 5 & Very Poor & 1 & 6.67 & 2 & 13.3 \\
\hline \multicolumn{2}{|c|}{ Totals } & 15 & 100 & 15 & 100 \\
\hline
\end{tabular}

Description: $F=$ Frequency, $\%=$ Percentage

From the table above, it can be seen that the coordination level of male basketball athletes of FIK
UNP at the beginning was good, considering that the highest frequency was in good criteria, with 5 people or $33.35 \%$. At the end, the level of coordination male basketball athletes of FIK UNP was poor, considering that the highest frequency was in poor criteria, with 6 people or $40.02 \%$. Meanwhile, based on the average level of coordination, there was an increase of 11.58 , so it can be said that there has been a development in the level of coordination in men's basketball athletes, FIK UNP.

\section{Endurance Test}

From the test results, the level of endurance of male basketball athletes of FIK UNP can be categorized Table 11. Endurance Test

\begin{tabular}{|c|c|c|c|c|c|}
\hline \multirow{2}{*}{ No } & \multirow{2}{*}{ Criteria } & \multicolumn{2}{|c|}{ Start } & \multicolumn{2}{c|}{ End } \\
\cline { 3 - 6 } & & $\mathrm{F}$ & $\%$ & $\mathrm{~F}$ & $\%$ \\
\hline 1 & Excellent & 0 & 0 & 0 & 0 \\
\hline 2 & Good & 5 & 33.35 & 5 & 33.35 \\
\hline 3 & Moderate & 5 & 33.35 & 6 & 40.02 \\
\hline 4 & Poor & 3 & 20.01 & 2 & 13.34 \\
\hline 5 & Very Poor & 2 & 13.34 & 2 & 13.34 \\
\hline \multicolumn{2}{|c|}{ Totals } & 15 & 100 & 15 & 100 \\
\hline
\end{tabular}

Description: $\mathrm{F}=$ Frequency, $\%=$ Percentage

From the table above, it can be seen that the level of endurance of male basketball athletes of FIK UNP at the beginning was good, considering that the highest frequency was in moderate criteria, with 5 people or $33.35 \%$. At the end, the level of endurance of male basketball athletes of FIK UNP was good, considering that the highest frequency was in moderate, with 6 people or $40.02 \%$. Meanwhile, based on the average level of endurance there was an increase of 1.12 , so it can be said that there has been a development in the level of endurance of male basketball athletes of FIK UNP.

\section{Power Test}

From the test results, the power level of male basketball athletes of FIK UNP can be categorized. The calculations are presented in the table as follows: 
Table 12. Power Test

\begin{tabular}{|c|c|c|c|c|c|}
\hline \multirow{2}{*}{ No } & \multirow{2}{*}{ Criteria } & \multicolumn{2}{|c|}{ Start } & \multicolumn{2}{c|}{ End } \\
\cline { 3 - 6 } & & $\mathrm{F}$ & $\%$ & $\mathrm{~F}$ & $\%$ \\
\hline 1 & Excellent & 1 & 6.67 & 1 & 6.67 \\
\hline 2 & Good & 5 & 33.35 & 6 & 40.02 \\
\hline 3 & Moderate & 5 & 33.35 & 6 & 40.02 \\
\hline 4 & Poor & 2 & 13.34 & 3 & 20.01 \\
\hline 5 & Very Poor & 2 & 13.34 & 1 & 6.67 \\
\hline \multicolumn{2}{|c|}{ Totals } & 15 & 100 & 15 & 100 \\
\hline
\end{tabular}

Description: $F=$ Frequency, $\%=$ Percentage

From the table above, it can be seen that the power level of male basketball athletes of FIK UNP at the beginning was in moderate criteria, with the consideration that the highest frequency was in moderate, with 5 people or $33.35 \%$. At the end, the power level of male basketball athletes of FIK UNP was in poor, considering that the highest frequency was in moderate, with 6 people or $40.02 \%$. Meanwhile, based on the average power level there was a decrease of 1.50 , so it can be said that there was no development of the power level of male basketball athletes of FIK UNP.

\section{Discussion}

This study aims to determine the development of biomotor components of male basketball athletes of FIK UNP. The results showed that at the speed level there was an increase in speed by 0.9 seconds; at the level of flexibility there was an increase of 1.3 ; at the level of muscle strength of the right finger there was an increase in strength by 0.84 ; the level of muscle strength of the left finger increased by 0.75 ; at the level of arm muscle strength there was an increase of 12.50; in the level of abdominal muscle strength there was an increase of 3.15; at the level of back muscle strength there was an increase of 5.32; at the agility level there was an increase of 0.20 ; at the level of coordination there was an increase of 11.58; at the level of endurance there was an increase of 1.12; and at the power level there is a decrease of 1.50 .

Based on the results obtained, it shows that there has been a development of biomotor components of male basketball athletes of FIK UNP. However, the developments that occur are not so prominent, so it can be said that the biomotor component of athletes still needs an exercise program to improve its quality. Of all the biomotor components owned by male basketball athletes of FIK UNP only the biomotor power component decreased by 1.00 . And the most striking increase is an increase in the biomotor component of coordination. The coordination biomotor component is the component that gets the most opportunity to get the most treatment. This is due to the pattern of basketball playing which has a basis for playing the ball by passing and catching the ball. This activity is almost the same as the coordination test carried out, so that the best improvement factors can be identified.

Basketball players tend to have a tall stature, and basketball players' height gives them an advantage in scoring points or blocking opposing players [6].

The goals of sports activities that are owned by each athlete become a separate requirement to be able to encourage the achievement of these goals. For athletes who want to achieve the highest performance, they must be able to train hard. Programmed and regular practice will have a positive contribution to the development of skills, as well as to abilities. The development of biomotor components in athletes will help athletes to be able to play optimally. A regional sports week event which is held every 2 years is a very prestigious event for each district so that it requires maximum struggle. Training programs must be structured as well as possible, in order to improve the abilities of athletes individually and as a team.

The development of significant physical, technical and mental abilities is the main target for achieving the best performance. With the development of this biomotor ability, it shows that the exercise that has been done is successful. Anthropometry and biomotor in athletes are things that vary according to sport. This varies due to different training models in athletes, thus 
leading to differences [7]. This study can help in recruiting players and improving training programs.

In particular, the development of biomotor components in basketball is very supportive of playing skills. This is because basketball is a big ball game played by two teams, and to find as many scores as possible by inserting the ball into the opponent's basketball and preventing the opponent from getting a score [8]. So that the development of biomotor components is very good to support solid teamwork. The selection of positions to play basketball should include analysis of the anthropometric and bimotor components, because they are a fundamental element in choosing a position to play basketball [9].

\section{CONCLUSION}

The results showed that the body mass index was 22.3 in the normal category, at the speed level there was an increase in speed of 0.15 seconds, at the flexibility level there was an increase of $1.00 \mathrm{~cm}$, at the right finger muscle strength level there was an increase in muscle strength of $0.85 \mathrm{~kg}$, at the level of left finger muscle strength there was an increase of $1.50 \mathrm{~kg}$, at the level of arm muscle strength there was an increase of 11.55, at the level of strength of the abdominal muscles there was an increase of 5.15, at the level of back muscle strength there was an increase of 7.85 , at the agility level there was an increase of 0.20 seconds, at the coordination level there was an increase of 13.70 , at the endurance level there was an increase of 1.25 and at the power level there was a decrease of $1.15 \mathrm{~cm}$. Suggestions for coaches, coaches must be able to become facilitators for athletes, so that athletes can improve their anthropometric and biomotor abilities.

\section{REFERENCES}

[1] Arikunto, S. (2016). Prosedur Penelitian Suatu Pendekatan Praktik. Jakarta: Rineka Cipta

[2] Burns et al. 2012. Athlete identity and athlete satisfaction: The nonconformity of exclusivity.
Journal Personality and Individual Differences Vol 52

[3] FIBA. 2018. Official basketball rules. Switzerland: FIBA Central Board.

[4] Mala., L. 2015. Body composition of elite female players in five different sports games. Journal of Human Kinetics volume 45

[5] Nalcakan., G. 2013. Anthropometric and biomotor variables of judokas in the turkish national young team. Journal of Physical Education And Sport Sciences Vol 7

[6] Parthiban., 2012. Analysis of selected bio-motor and hockey skills factors among south zone inter University men hockey players. International journal of behavioral social and movement sciences

[7] Pomohaci., M dan Sopa S., I. 2017. The importance of anthropometry measurements in analyzing the impact of sports activities on students. Journal Land Forces Academy Review Vol. XXII, No 1(85), 2017

[8] Rajan., N and Ahamed Faiz PA .2018. Plyometric training on selected bio motor abilities of basketball players. International Journal of Physiology, Nutrition and Physical Education

[9] Sukadiyanto. 2010. Metodologi Melatih Fisik. Universitas Negeri Yogyakarta. Yogyakarta 